\title{
Studies on Chemical Disbudding of Chrysanthemum
}

\author{
Yukihiro Fujime \\ Faculty of Agriculture, Kagawa University, \\ Miki Cho, Kida Gun, Kagawa Ken
}

\begin{abstract}
Summary
The effect of some chemicals on disbudding mainly of chrysanthemum and the methods of treatment were investigated.

1. Sodium chlorate and Tomino, a 90\% emulsion of ethyl toluene, tri-methyl benzene and $\mathrm{C}_{8}$ to $\mathrm{C}_{12}$ fatty acids, were the most effective disbudding agents for 'Taibyosei-FR-1' tomato. Browning of leaves was more noticeable with sodium chlorate.

2. Symptoms of disbudding appeared early in tomato treated with Tomino at the point of application of the chemical.

3. Tomino and $\alpha$-methyl naphthalene were most effective for chemical disbudding of 'Kiyomizu' chrysanthemum.

4. The application of $2 \%$ Tomino to four cultivars of pot mum resulted in disbudding of axillary buds below the 4 th or 5 th node from the terminal bud in all cultivars.

5. Treatment with 1 or $2 \%$ Tomino to seven cultivars of pot mum was most effective when the buds had received fourty-five short days. The long day interruption for one week during the short day induction had little effect on disbudding.

6. Tomino inhibited stem elongation slightly.
\end{abstract}

\section{Introduction}

Although various labor-saving methods have been introduced into cultivation through the use of growth regulators, jobs such as pruning, pinching and disbudding still depend largely on human labor. The growth and development of the lateral buds and branche sare subjected mostly to apical dominance by the shoot apex. Though the involvement of hormones in apical dominance has been indicated (13), their influence on the regulatory mechanisms is yet obscure.

The use of chemicals for pinching and disbudding in practical cultivation has come into common use for specific crops such as tobacco and azalea. The difficulty of their use for other crops is due to the fact that the bud tissues for disbudding are immature, their resistance to chemicals is wcak, and there are some axillary buds around the bud. But in recent years there have been reports on the use of some chemicals that destroy actively growing meristematic tissues without affecting

Received for publication May 22, 1978. more mature leaf and stem tissues $(2,3,4,5$, $6,7,8,9,12,15,16,17,18,19,20)$.

This study deals with the effects of some chemicals used for disbudding in chrysanthemum and the methods of treatment.

\section{Materials and Methods}

Preliminary experiment. Lycopersicon esculentum Mill. cv. 'Taibyosei-FR-1' was used; it was seeded in a hotbed on February 5, 1970 and planted in open field on April 15. The plants were topped at the $3 \mathrm{rd}$ leaf above the 6 th flower cluster; lateral buds and branches were not removed. In each treatment, ten plants about $2 \mathrm{~m}$ high were used and a total of 100 axillary buds about $5 \mathrm{~mm}$ long from lateral shoots were treated. The following eight chemicals were sprayed onto the plants: 1) distilled water; 2) sodium chlorate $(1.5 \%)$; 3) Tomino $(1,2 \%)$, a $90 \%$ emulsion of ethyl toluene, tri-methyl benzene and $\mathrm{C}_{8}$ to $\mathrm{C}_{12}$ fatty acids; 4) $\alpha$-methyl naphthalene $(0.125,0.25 \%)$; 5) $\beta$-methyl naphthalene $(0.125,0.25 \%)$; 6) naphthalene $(67,100 \%)$; 7) acenaphthene $(33,100 \%)$ and 8) maleic 
hydrazide $(0.1 \%)$. Chemicals of nos. 2,3 and 8 were sprayed as aqueous solution and chemicals of nos. 4, 5, 6 and 7 were sprayed as solution in acetone: water, $4: 6$ by volume. For naphthalene and acenaphthene, a saturated solution of the chemical in the 4 : 6 , acetone: water mixture is called a $100 \%$ solution, a $1: 3$ dilution mixture is called 33 $\%$ and a $2: 3$ dilution is called $67 \%$. The axillary buds were sprayed once to run-off with a small hand atomizer, using $0.5 \%$ Tween-20 as the wetting agent. The extent of leaf injury caused by the treatment of chemicals was grouped as slight $(t)$, moderate (H) and severe (H) based on the browning area. The disbudding effect on the 5 th and 15 th days after treatment with $2 \%$ Tomino, which was sprayed on 0,1 and 2 days after pinching respectively, was also investigated.

Experiment 1. This experiment was done in a greenhouse to investigate the disbudding effect of some chemicals on chrysanthemum.

The 1 st experiment. The disbudding effects of nine chemicals and their dosage were studied. Three cuttings of Chrysanthemum morifolium Ram. cv. 'Kiyomizu' were potted in a $15 \mathrm{~cm}$ clay pot on April 3, 1971; they were pinched to have three shoots on April 10 and were grown under natural day-length. After the 15 th leaf of every shoot opened, the plants were transferred to 8-hour day-length on May 18, 1971. On June 3, the plants were returned to natural long day-length and sprayed with chemicals to run-off once at the evening of June 12. After spraying, the plants were grown in 8-hour day-length to flowering. The following nine chemicals were sprayed onto the plants: 1) distilled water; 2) Tomino $(1,2,3 \%)$; 3) Ekatin (2, 3\%), a 25\% emulsion of the insecticide, thiometon; 4) OffShoot-O $(0.25,0.50 \%)$, a $42 \%$ emulsion of fatty acids; 5) toluene $(2,3 \%) ; 6$ ) xylene $(2,3 \%)$; 7) p-cymene $(2,3 \%)$; 8) $\alpha$-methyl naphthalene $(2,3 \%) ; 9)$ maleic hydrazide $(1 \%)$. Each treatment consisted of eighteen shoots. Each chemical solution, containing $0.5 \%$ Tween-20, was sprayed $50 \mathrm{~m} l$ per pot onto the entire plant with a small hand atomizer.

The 2 nd experiment. The selective effectiveness of disbudding agents was studied.
Using four cultivars of pot mum, 'Golden Princess Anne,' 'Blue Ridge,' 'Pink Magic' and 'Princessa d'Oro,' the effects of Tomino and Off-Shoot-O were studied. Three cuttings were potted on January 14, 1971 and pinched to have three shoots on January 20 in a greenhouse where a minimum night temperature of $10^{\circ} \mathrm{C}$ was maintained from December 10 , 1970 to March 31, 1971. The plants were grown under natural day-length till March 11 and received 8-hour day-length for twentyfive days from March 11 to April 5 and returned to natural day-length on April 6. They were sprayed on April 16 and were transferred to 8-hour day-length from April 25 to flowering. The following three chemical solutions were sprayed $20 \mathrm{ml}$ per pot onto the entire plant : 1) distilled water ; 2) Off-Shoot-O $(8 \%)$; 3) Tomino (2\%). Each treatment consisted of eighteen shoots.

The $3 \mathrm{rd}$ experiment. The treatment time was studied. 'Kiyomizu' chrysanthemum was potted on April 3, 1971 and pinched to have three shoots on April 10 and transferred to 8-hour day-length from May 6 to flowering. On May 16, 21, 27 and 31 (the 10 th, 15 th, 21 st and 25 th short day plots), the plants were sprayed $20 \mathrm{~m} l$ per pot with the following chemicals to investigate the effect of bud development stage in the treatment: 1 ) distilled water ; 2) Tomino (2, 3\%); 3) Off-Shoot-O $(5 \%)$. Each treatment consisted of nine shoots. When thebuds were colored, they were calculated as flowering.

Experiment 2. This experiment was done in a plastic house to investigate the effects of bud development stage and pre-treatment, interruption with seven long days during inductive short days, on disbudding in chrysanthemum. Pre-treatment was employed to delay the reproductive development of axillary buds and to enhance the disbudding effect. Seven cultivars of pot mum, 'Jack Straw,' 'Bright Golden Anne,' 'Pink Magic,' 'Blue Ridge,' 'Subaru,' 'Golden Princess Anne' and 'Princessa d'Oro,' were potted and grown under the same way as previously stated. The plants received 8-hour day-length beginning on July 12, 1971. On August 9, 14 and 19 (the 28th, 33 rd and 38 th short day plots) the plants were divided into two groups. One group received 
continuous 8-hour day-length and the other received 24-hour day-length for seven days (the plants were illuminated with fluorescent lamps from sunset to sunrise). The plants of each plot were sprayed with Tomino on August 16, 21 and 26 respectively and they were returned to 8-hour day-length to flowering. Each treatment consisted of eighteen shoots. With respect to methods of application, $2 \%$ Tomino was sprayed once to the 28 th short day plot and the secondary repeated applications, three days after the first spray application, of $1 \%$ Tomino were done to the $33 \mathrm{rd}$ and 38 th short day plots. As to control, distilled water containing 0.5 $\%$ Tween-20 was sprayed $30 \mathrm{~m} l$ per pot onto entire plants.

\section{Results}

Preliminary experiment. Percentages of inactivated buds with sodium chlorate, $1 \%$ Tomino and 2\% Tomino were 76, 22 and 64 $\%$ each (Table 1 ). The extent of leaf injury was wide and severe especially in the treatment with sodium chlorate. Leaf injury with Tomino was less than with sodium chlorate. Though $\alpha$-methyl naphthalene and acenaphthene showed lower percentages in disbudding of axillary buds, the extent of leaf injury was severe and wide respectively. High percentages of disbudding were obtained with Tomino within five days of beginning

Table 1. Effects of some chemicals on axillary buds and extent of leaf injury of tomato in one month after treatment.

\begin{tabular}{|c|c|c|c|c|}
\hline \multirow{2}{*}{\multicolumn{2}{|c|}{ Treatment }} & \multirow{2}{*}{$\begin{array}{c}\text { Axillary } \\
\text { buds } \\
\text { killed }\end{array}$} & \multicolumn{2}{|c|}{ Leaf injury } \\
\hline & & & $+\#$ & $H$ \\
\hline distilled water & & $0 \%$ & $0 \%$ & $0 \%$ \\
\hline sodium chlorate & $1.5 \%$ & 76 & 72 & 6 \\
\hline Tomino & 1.0 & 22 & 23 & 7 \\
\hline Tomino & 2. 0 & 64 & 44 & 5 \\
\hline$\alpha$-methyl naphthalene & e 0.125 & 8 & 6 & 24 \\
\hline$\alpha$-methyl naphthalene & e 0.250 & 11 & 25 & 31 \\
\hline$\beta$-methyl naphthalene & 0.125 & 6 & 3 & 2 \\
\hline$\beta$-methyl naphthalene & 0.250 & 9 & 19 & 0 \\
\hline naphthalene & 67 & 8 & 19 & 5 \\
\hline naph thalene & 100 & 4 & 22 & 2 \\
\hline acenaphthene & 33 & 10 & 36 & 2 \\
\hline acenaphthene & 100 & 13 & 39 & 2 \\
\hline maleic hydrazide & 0.1 & 6 & 6 & 0 \\
\hline
\end{tabular}

\# The extent of leaf injury was grouped as slight $(t)$, moderate (H), and severe (H). treatment (Table 2).

Experiment 1. Though terminal and axillary buds above the 6 th node were not killed, many axillary buds were killed below the 6 th with $1 \%$ Tomino in the 1 st experiment (Table 3). Higher effect of disbudding was shown on every node with 2 and $3 \%$ Tomino and Ekatin. Off-Shoot-O did not show disbudding effect, perhaps because of its low concentration. Two $\%$ toluene showed lower effect on higher nodes and higher effect on lower nodes, but $3 \%$ toluene and xylene showed higher effect on every node. P-cymene had little effect on disbudding. Though terminal flower buds were not affected with $2 \% \quad \alpha$-methyl naphthalene, higher effect of disbudding was shown with $3 \% \alpha$-methyl naphthalene. Maleic hydrazide affected only the buds from the 1 st to the 4 th nodes. The effect of chemicals on growth and development of flower buds was not observed. There was scarcely any difference between the flower buds of the control and buds treated with $1 \%$ Tomino and $2 \%$ $\alpha$-methyl naphthalene. Slight browning in plants was shown only on stems in each treatment with $1 \%$ Tomino and $2 \% \quad \alpha$-methyl naphthalene. Occurence of plant injury was frequent in the treatment which showed a high disbudding effect.

In the 2 nd experiment, high disbudding effect was seen in the treatment with Off-Shoot-O on every node of every cultivar, perhaps on account of its high concentration; there was almost no selective resistance to disbudding agents by bud position (Fig. 1). In treatment with $2 \%$ Tomino, the flower buds of four cultivars, from the 1 st to the 4 th or the 5 th node, were not killed or inactivated and flowered normally. But buds below the 4 th

Table 2. Effect of time of treatment with Tomino on axillary buds in tomato.

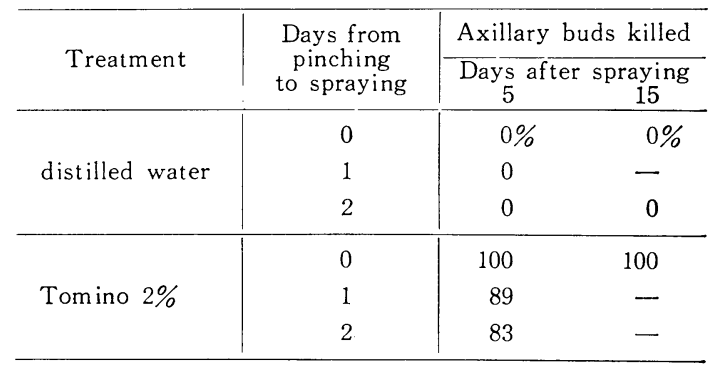


Table 3. Effects of some chemicals on disbudding, flowering and plant injury in 'Kiyomizu'.

\begin{tabular}{|c|c|c|c|c|c|c|c|c|c|c|c|c|c|c|c|c|c|c|c|}
\hline \multirow{2}{*}{ Treatment } & \multicolumn{15}{|c|}{ Terminal and axillary flower buds killed (\%) } & \multirow{2}{*}{$\begin{array}{c}\text { Flowering } \sharp \sharp \\
(\%)\end{array}$} & \multicolumn{3}{|c|}{ Plant injury } \\
\hline & 1\# & 2 & 3 & 4 & 5 & 6 & 7 & 8 & 9 & 10 & 11 & 12 & 13 & $\begin{array}{c}14 \\
\text { Node }\end{array}$ & $\begin{array}{c}15 \\
\text { order }\end{array}$ & & Leaf & Stem & Bud \\
\hline distilled water & 0 & 0 & 0 & 0 & 0 & 0 & 0 & 0 & 0 & 0 & 0 & 0 & 0 & 0 & 0 & 100 & - & - & - \\
\hline Tomino $1 \%$ & 0 & 7 & 0 & 0 & 7 & 7 & 64 & 36 & 29 & 58 & 58 & 64 & 50 & 50 & 64 & 100 & - & \pm & - \\
\hline Tomino $2 \%$ & 100 & 100 & 100 & 100 & 100 & 100 & 83 & 83 & 83 & 67 & 58 & 75 & 58 & 58 & 67 & 0 & \pm & + & + \\
\hline Tomino $3 \%$ & 100 & 100 & 100 & 100 & 100 & 100 & 100 & 100 & 93 & 93 & 71 & 57 & 64 & 71 & 64 & 0 & \pm & + & + \\
\hline Ekatin $2 \%$ & 67 & 87 & 87 & 87 & 93 & 87 & 80 & 93 & 93 & 100 & 93 & 93 & 93 & 93 & 100 & 20 & + & + & + \\
\hline Ekatin $3 \%$ & 100 & 100 & 100 & 100 & 100 & 100 & 93 & 100 & 100 & 100 & 100 & 100 & 100 & 100 & 100 & 0 & + & + & + \\
\hline Off-Shoot-O $0.25 \%$ & 0 & 0 & 0 & 0 & 0 & 0 & 0 & 0 & 0 & 0 & 0 & 0 & 0 & 0 & 0 & 67 & - & - & - \\
\hline Off-Shoot-O 0.50 & 0 & 0 & 0 & 0 & 0 & 0 & 0 & 0 & 0 & 0 & 0 & 0 & 0 & 0 & 0 & 40 & - & - & - \\
\hline toluene $2 \%$ & 42 & 42 & 42 & 33 & 42 & 42 & 58 & 67 & 83 & 83 & 92 & 83 & 83 & 83 & 83 & 50 & \pm & + & + \\
\hline toluene & 67 & 89 & 78 & 78 & 89 & 89 & 100 & 100 & 100 & 100 & 100 & 100 & 100 & 100 & 100 & 22 & + & + & + \\
\hline xylene & 100 & 91 & 82 & 82 & 82 & 64 & 64 & 64 & 64 & 65 & 82 & 64 & 64 & 64 & 73 & 0 & - & + & - \\
\hline xylene & 93 & 93 & 93 & 87 & 80 & 87 & 87 & 73 & 73 & 73 & 80 & 73 & 80 & 100 & 100 & 0 & \pm & + & + \\
\hline p-cymene $2 \%$ & 0 & 8 & 0 & 25 & 17 & 8 & 8 & 0 & 0 & 0 & 0 & 8 & 0 & 0 & 0 & 92 & - & - & - \\
\hline p-cymene $3 \%$ & 0 & 0 & 13 & 0 & 0 & 13 & 7 & 7 & 0 & 0 & 0 & 7 & 7 & 7 & 7 & 53 & - & - & - \\
\hline $\begin{array}{l}\alpha \text {-methyl } \\
\text { naphthalene } 2 \%\end{array}$ & 0 & 8 & 33 & 58 & 67 & 75 & 100 & 100 & 100 & 92 & 100 & 100 & 100 & 100 & 100 & 92 & - & \pm & - \\
\hline $\begin{array}{l}\alpha \text {-methyl } \\
\text { naphthalene } 3 \%\end{array}$ & 85 & 77 & 100 & 100 & 69 & 69 & 85 & 62 & 85 & 85 & 100 & 100 & 100 & 92 & 100 & 8 & - & \pm & + \\
\hline $\begin{array}{c}\text { maleic } \\
\text { hydrazide } \quad 1 \%\end{array}$ & 45 & 27 & 27 & 9 & 0 & 0 & 0 & 0 & 0 & 0 & 0 & 0 & 0 & 0 & 0 & 0 & - & - & + \\
\hline
\end{tabular}

Terminal flower bud. \# Colored buds. (Five weeks after treatment.)

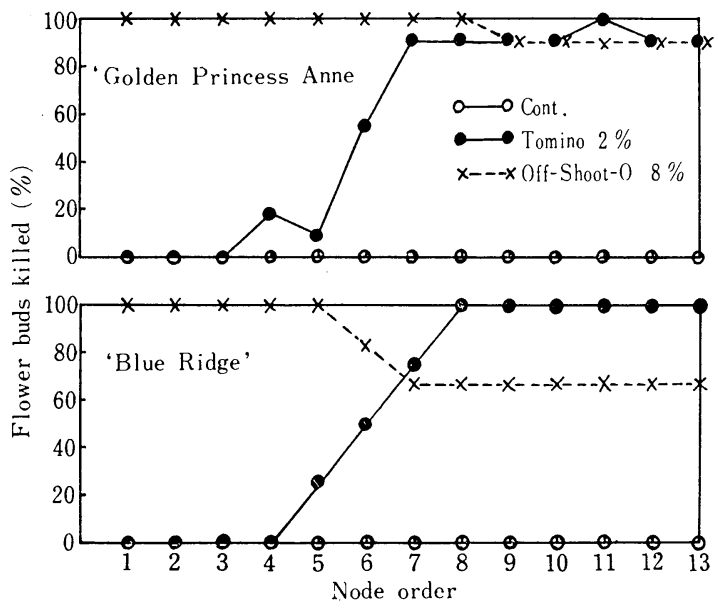

Fig. 1. Effects of Tomino and Off-Shoot-O on disbudding of terminal (1) and axillary flower buds (2-13).

or the 5 th node were killed, the disbudding effect being high on all cultivars. In the treatment with Tomino, though the terminal flower bud and the two axillary flower buds were in bloom, axillary buds below the $3 \mathrm{rd}$ node did not appear (Fig. 2). But in the control, eight flower buds were in bloom and buds grew below the 8 th node. No effect of Tomino on the diameter was recognized in 'Golden Princess Anne' and 'Blue Ridge,' but

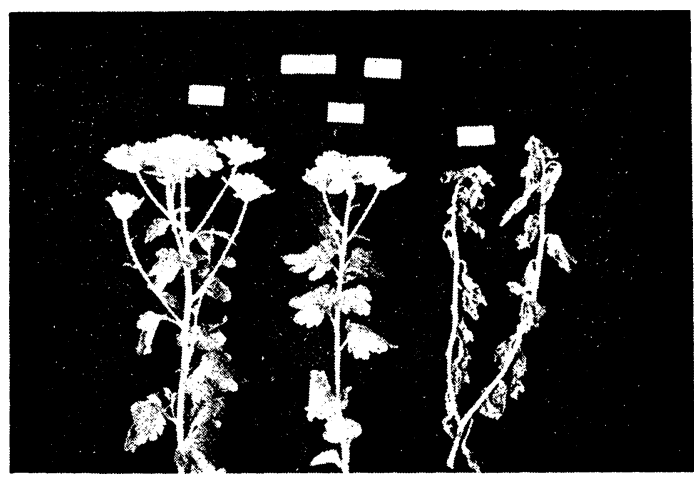

Fig. 2. Plants of 'Golden Princess Anne' treated with Tomino and Off-Shoot-O. Left to right: control, treated with Tomino, treated with Off-Shoot-O.

Table 4. Effects of Tomino on diameter of flower buds and stem length.

\begin{tabular}{|c|c|c|c|c|c|c|}
\hline \multirow[b]{2}{*}{ Cultivar } & \multirow[b]{2}{*}{ Treatment } & \multicolumn{4}{|c|}{ Diameter of flower buds } & \multirow{2}{*}{$\begin{array}{l}\text { Stem } \\
\text { length }\end{array}$} \\
\hline & & $1 \#$ & $\begin{array}{c}\text { Node } \\
2\end{array}$ & $\begin{array}{c}\text { order } \\
3\end{array}$ & 4 & \\
\hline \multirow{3}{*}{$\begin{array}{l}\text { 'Golden } \\
\text { 'Princess } \\
\text { Anne' }\end{array}$} & \multirow{3}{*}{$\begin{array}{l}\text { Cont. } \\
\text { Tomino } 2 \%\end{array}$} & 7. $2^{\mathrm{cm}}$ & 5. 9 & $\begin{array}{l}\text { cm } \\
6.2\end{array}$ & $\begin{array}{l}{ }^{\mathrm{cm}} \\
5.8\end{array}$ & $\begin{array}{l}{ }^{\mathrm{cm}} \\
30.6^{-}\end{array}$ \\
\hline & & 7.3 & 6.4 & 5.9 & 7. 2 & 29.4 \\
\hline & & N. S. & N. S. & N.S. & N.S. & N.S. \\
\hline \multirow{3}{*}{$\begin{array}{l}\text { 'Blue } \\
\text { Ridge' }\end{array}$} & \multirow{3}{*}{$\begin{array}{l}\text { Cont. } \\
\text { Tomino } 2 \%\end{array}$} & 7.6 & 5.2 & 5. 6 & 5.0 & 19. 2 \\
\hline & & 7.8 & 6.6 & - & - & 13. 4 \\
\hline & & N.S. & N.S. & & & $* *$ \\
\hline
\end{tabular}

\# Terminal flower bud. 

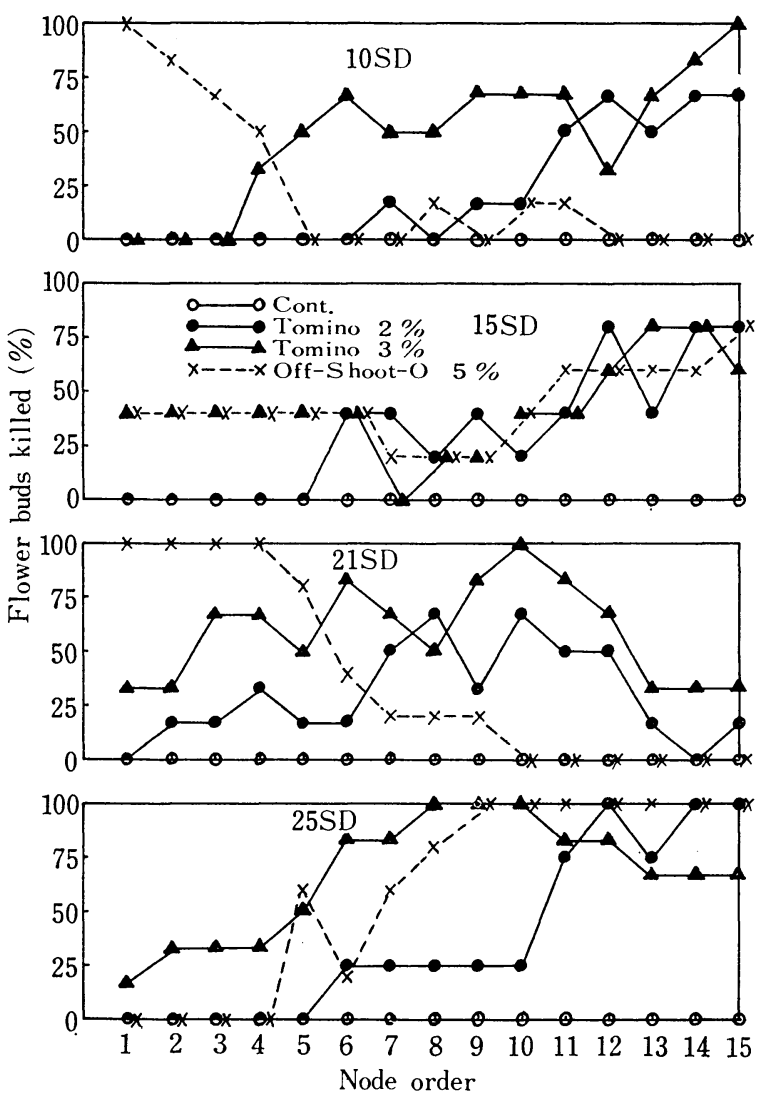

Fig. 3. Effects of short day period on disbudding in 'Kiyomizu' treated with Tomino and Off-Shoot-O.

the growth of stem was inhibited in 'Blue Ridge' (Table 4).

In the $3 \mathrm{rd}$ experiment, disbudding effect with $2 \%$ Tomino was low in every stage and its effect was shown on the buds below the 6 th node (Fig. 3). The disbudding effect with $3 \%$ Tomino showed the same pattern as with $2 \%$ Tomino but its effect was a little higher on the buds of every node than with $2 \%$ Tomino. Most of the flower buds treated with Off-Shoot-O above the 5 th node were killed in 10,15 and $21 \mathrm{SD}$ applications, but in $25 \mathrm{SD}$, whereas flower buds above the 4 th node were not killed, the buds below the 4 th node were almost all killed as with Tomino. Decrease in the stem length was more conspicuous with Tomino (Table 5). The diameter of flower buds treated with Tomino did not differ from that of the control.

Experiment 2. The pattern of disbudding effect on 'Jack Straw' was similar to that of the other six cultivars of pot mum. Disbudding effect on flower buds from the 1 st to the 5 th or the 6 th node was higher than on other nodes and there were no difference between plants given continuous 8 hour day-length and those given long day interruption in $28 \mathrm{SD}$ (Fig. 4). In $33 \mathrm{SD}$, the disbudding effect from the 1 st to the $3 \mathrm{rd}$ or the 4 th node decreased and the disbudding effect on the buds below the 3 rd or the 4 th node increased compared with $28 \mathrm{SD}$. The tendency was more prominent under continuous short day-length than under interruption with long day-length. In $38 \mathrm{SD}$, the number of buds which survived increased in upper node but the buds below 5 th node were almost all killed. There was scarcely any difference between plants given continuous short day-length and those given interruption with long day-length. Axillary flower buds were killed within one week after treatment (Fig. 5). Under continuous short day-length, stem growth was inhibited in $28 \mathrm{SD}$ and $38 \mathrm{SD}$ (Table 6). It was also inhibited in $28 \mathrm{SD}$ under interruption with long day-length. Leaf injury was sometimes seen in $28 \mathrm{SD}$ but scarce in $33 \mathrm{SD}$ and $38 \mathrm{SD}$. Flowering of 'Pink Magic' was not delayed by the treatment with Tomino and leaf injury was not seen in treatment with Tomino (Fig.

Table 5. Effects of treatment with Tomino and Off-Shoot-O on growth and development in 'Kiyomizu'.

\begin{tabular}{|c|c|c|c|c|c|c|c|c|}
\hline \multirow{2}{*}{ Treatment } & \multicolumn{2}{|c|}{$10 \mathrm{SD}$} & \multicolumn{2}{|c|}{$15 \mathrm{SD}$} & \multicolumn{2}{|c|}{$21 \mathrm{SD}$} & \multicolumn{2}{|c|}{$25 \mathrm{SD}$} \\
\hline & Stem length & $\begin{array}{l}\text { Diameter } \\
\text { of flower }\end{array}$ & Stem length & $\begin{array}{l}\text { Diameter } \\
\text { of flower }\end{array}$ & Stem length & $\begin{array}{l}\text { Diameter } \\
\text { of flower }\end{array}$ & Stem length & $\begin{array}{l}\text { Diameter } \\
\text { of flower }\end{array}$ \\
\hline Cont. & $25.7 \mathrm{~cm}$ & $3.8 \mathrm{~cm}$ & $29.0 \mathrm{~cm}$ & $3.2 \mathrm{~cm}$ & $29.0 \mathrm{~cm}$ & $3.4 \mathrm{~cm}$ & $25.8 \mathrm{~cm}$ & $3.7 \mathrm{~cm}$ \\
\hline Tomino $2 \%$ & 23.6 & 3.5 & 22.3 & 3.7 & 26.5 & 3.6 & 26.4 & 3.5 \\
\hline Tomino $3 \%$ & 18.5 & 2.9 & 17.1 & 3.7 & 22.2 & 3.9 & 20.1 & 3. 6 \\
\hline Off-Shoot-O $5 \%$ & 9.5 & 一 & 26.3 & 3.9 & 19.4 & 一 & 23.2 & 3.7 \\
\hline D 0.05 & 7.3 & 0.5 & 6.5 & 0.4 & 6.5 & 0.7 & 7.7 & 0.5 \\
\hline
\end{tabular}




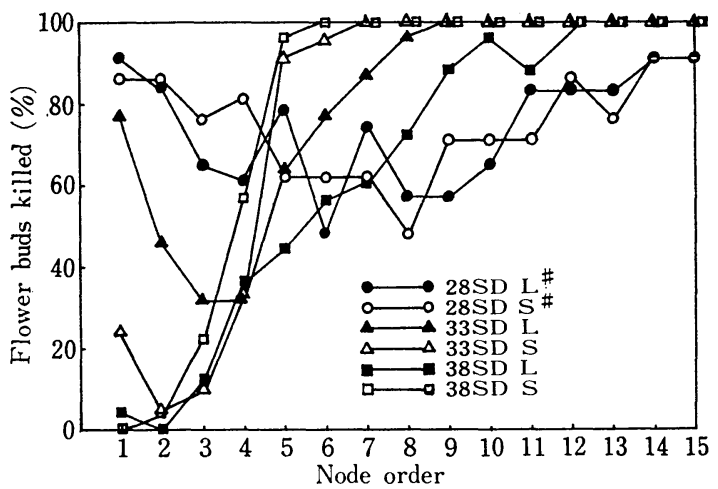

Fig. 4. Relation of bud developmental stage of buds to interruption with long day-length on disbudding of 'Jack Straw' treated with Tomino in five weeks after treatment.

\# L: interrupted with long day-length. $\mathrm{S}$ : continuous short day-length.

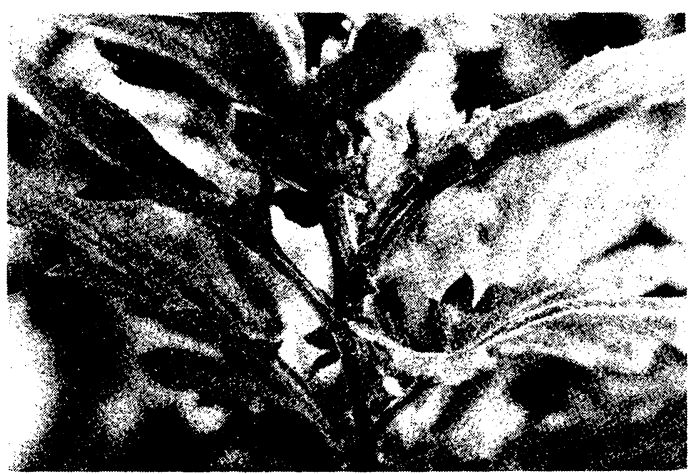

Fig. 5. Axillary flower buds of 'Blue Ridge', one week after treatment with Tomino.

$6)$.

\section{Discussion}

From the results of these experiment it may be concluded that Tomino is the most effective disbudding agent because of its high disbudding effect and slight degree of plant injury.

As to the effect of Tomino on tomato, browning was seen only in the plots stained with chemicals and was apparent within 30-60 minutes after spraying. From these results it was concluded that Tomino is effective as a disbudding agent when used as a direct contact herbicide. As tomato has a flower cluster on every third leaf, it is necessary to use a disbudding agent to which the flower cluster is resistant.

Though the terminal flower buds were not
Table 6. Effects of bud development stage and interruption with long day-length in treatment with Tomino on elongation of stem in 'Jack Straw.

\begin{tabular}{|c|c|c|c|c|c|c|}
\hline \multirow{2}{*}{\multicolumn{4}{|c|}{ Treatment }} & \multicolumn{3}{|c|}{ Stem length } \\
\hline & & & & $\begin{array}{c}\text { before } \\
\text { spraying }\end{array}$ & $\begin{array}{r}4 \text { weeks } \\
\text { treatn }\end{array}$ & $\begin{array}{l}\text { after } \\
\text { nent }\end{array}$ \\
\hline \multirow{2}{*}{$28 \mathrm{SD}$} & $L \#$ & $\begin{array}{l}\text { Cont. } \\
\text { Tom ino }\end{array}$ & $2 \%$ \#\# & $\begin{array}{l}10.3 \mathrm{~cm} \\
10.3\end{array}$ & $\begin{array}{l}13.1 \\
10.9\end{array}$ & $\mathrm{~cm}$ \\
\hline & & $\begin{array}{l}\text { Cont. } \\
\text { Tomino }\end{array}$ & $2 \%$ & $\begin{array}{l}10.4 \\
10.4\end{array}$ & $\begin{array}{l}19.5 \\
12.0\end{array}$ & $* *$ \\
\hline \multirow{2}{*}{$33 \mathrm{SD}$} & & $\begin{array}{l}\text { Cont. } \\
\text { Tomino }\end{array}$ & $1 \%$ \#\# & $\begin{array}{l}10.9 \\
10.9\end{array}$ & $\begin{array}{l}14.5 \\
15.7\end{array}$ & N. S. \\
\hline & & $\begin{array}{l}\text { Cont. } \\
\text { Tomino }\end{array}$ & $1 \%$ & $\begin{array}{l}11.5 \\
11.5\end{array}$ & $\begin{array}{l}19.1 \\
17.1\end{array}$ & N. S. \\
\hline \multirow{2}{*}{$38 \mathrm{SD}$} & & $\begin{array}{l}\text { Cont. } \\
\text { Tomino }\end{array}$ & $1 \%$ & $\begin{array}{l}11.7 \\
11.7\end{array}$ & $\begin{array}{l}16.0 \\
17.7\end{array}$ & N. S. \\
\hline & & $\begin{array}{l}\text { Cont. } \\
\text { Tomino }\end{array}$ & $1 \%$ & $\begin{array}{l}14.0 \\
14.0\end{array}$ & $\begin{array}{l}21.3 \\
19.3\end{array}$ & $* *$ \\
\hline
\end{tabular}

\# L : interruption with long day-length.

$\mathrm{S}$ : continuous short day-length.

\#\# Single spraying \#\# Double spraying.

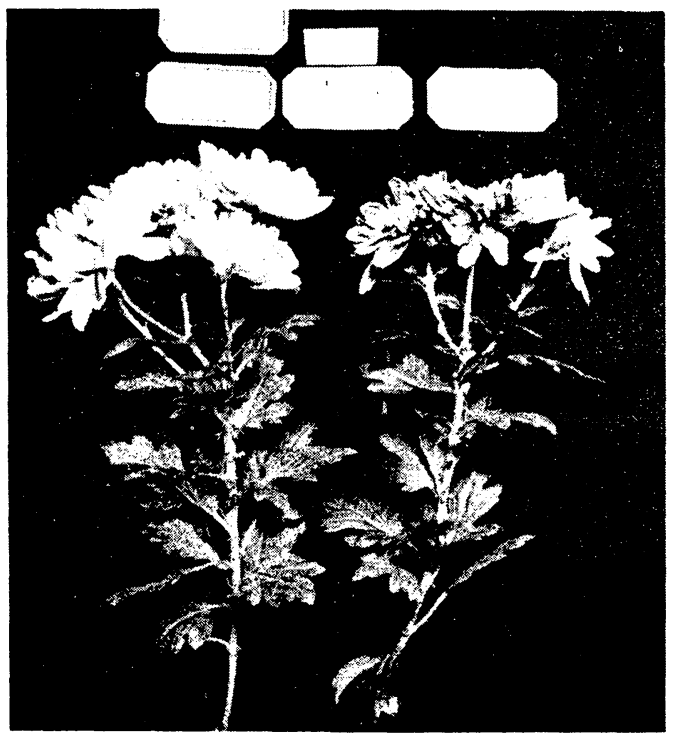

Fig. 6. Plants of 'Pink Magic' treated with Tomino. Left to right : control, treated with Tomino.

killed, almost all axillary flower buds were killed with Tomino in chrysanthemum. But the optimum time for spraying was limited to the time when the terminal flower buds had become well developed and the apical dominance of shoot had been broken. Though the organization of the terminal flower buds of chrysanthemum is not different from that of the axillary buds, the rate of development of upper buds differs greatly from that of lower buds because of its apical dominance. 
Therefore, difference of resistance to Tomino between upper flower buds and lower buds was apparent in the treatment. As in tomato, browning of axillary buds was seen soon after the treatment and browning of the stem was also seen in the plots where there was a direct contact with chemicals over a wide area. So the disbudding effect of Tomino in chrysanthemum may also be considered to be the effect of direct contact.

Chemicals used as disbudding or pinching agents, may fall into two main classes. Chemicals of first group, e.g. maleic hydrazide, are absorbed in to the growing point and grow th and development are inhibited $(1,10,14)$. In this experiment, when chrysanthemum was treated with maleic hydrazide, flower buds of upper four nodes were killed but axillary buds below the 4 th node were not killed. The second group includes fatty acids, fatty alcohols and aromatic compounds. The main constituents of Tomino, utilized in this experiment, are aromatic compounds and so belong to the second group. The effect of Tomino was entirely in line with the results of Steffens et al (16), Tso (17), Tso et al (18), Cathey et al $(2,3)$, Cathey $(4,5)$, Kofranek and Markiewicz (8), Zacharioudakis and Larso (20) and Parups (12) who utilized chemicals of the second group. Namely, as Cathey et al $(2,3)$ have already shown, these chemicals effectively and selectively killed axillary meristems without damaging mature leaf tissue. Growth inhibition or tissue death occurs only when the sprayed solution comes in direct contact with the meristematic tissue and the effect is soon apparent.

The use of chemicals for disbudding or pinching has been studied by a few investigators $(11,19)$. Nelson and Poteet (11) investigated the action of methyl decanoate on pinching of azalea and reported that direct contact of the chemical was necessary for pinching. They further state that varietal resistance develops because the penetration of chemicals is determined by the morphological nature of the epidermis, and the flower buds are more resistant than the vegetative buds because of their many leaves acting as barriers. This may explain why the resistance to chemicals differed slightly among various chrysanthemum cultivars and why well developed flower buds were resistant than immature flower buds in this experiment. Cathey et al (2) studied chemical disbudding of chrysanthemum together with HAN and Kofranek (9) utilizing aromatic compounds to kill the axillary flower buds of chrysanthemum. They concluded that the optimum time for treatment (as measured by the number of short days) was the 14 th-17 th short day. But in the present experiment, the optimum time for treatment was much later (cf. $33 \mathrm{SD}$ or $38 \mathrm{SD}$ in Experiment 2). Though there is a difference between the results of this experiment and those which used different cultivars and chemicals, there exists the same tendency that the later the treating time, the stronger the effect is. Klapwijk, van Veen and de Lint (6) reported that the application of Ekatin as early as the 9 th or 12 th short day damaged terminal flower buds and produced malformed leaves. They reported also a higher percentage of disbudding with the long day interruption in inductive short day-length than in continuous short daylength. But this auther did not get the same result.

In this experiment, the flower buds were treated later than in the other experiments cited in order to diminish the aborting of upper flower buds and to kill chiefly the flower buds below the 4 th node. Therefore, the optimum time for spraying in this experiment differed from theirs. In short, the method used by Cathey et al (2) to kill the buds was based on the difference between flower buds and vegetative buds in their resistance to chemicals, whereas that of the present experiment was based on the difference of developmental stage of the flower buds. There was no difference of the flowering date and the diameter of flower buds in chrysanthemum treated with Tomino than those of the control. The elongation of stem was slightly inhibited, however, an effect which was also reported by Kofranek and Markiewicz (8), Cathey (5) and Zacharioudakis and Larson (20).

\section{Acknowledgement}

This experiment was carried out on the Experimental Farm of the Faculty of Agricul- 
ture, Kyoto University, 1970 to 1971. The author wishes to express his sincere thanks to Professor T. Asahira of Kyoto University and Dr. Y. Ihara for their helpful suggestions during this study and in the preparation of the manuscript and to Dr. Y. Tsukamoto, Professor K. Ueki of Kyoto University and Professor T. Hirose of Kagawa University for their continuous encouragement and to Associate Professor K. Takeda of Kyoto University for giving kind advice.

The author wishes to thank Nihon Noyaku Co., Ltd., for providing their product Tomino and Kyowa Hakko Co., Ltd., for providing Off-Shoot-O for this experiment.

\section{Literature Cited}

1. BECK, G. E., L. HOLM and B. E. STRUCKMEYFR. 1957. The effect of maleic hydrazide on vegetative growth and flower production of carnation (Dianthus Caryophyllus, L.). Proc. Amer. Soc. Hort. Sci. 69 : 523-534.

2. Cathey, H. M., A. H. Yoeman and F. F. SMith. 1956. Abortion of flower buds in chrysanthemum after application of a selected petroleum fraction of high aromatic content. HortScience $1: 61-62$.

3. Cathey, H. M., G.L. Steffens, N. W. StUART and R.H. ZimMERMAN. 1966. Chemical pruning of plants. Science $153: 1382-1383$.

4. CATHEY, H.M. 1968. Reports of cooperative trial on chemical pruning of chrysanthemum with fatty acids esters. Florists ${ }^{\circ}$ Review $141: 19-21,87-90$.

5. CATHEY, H.M. 1976. Influence of a substituted oxathiin, a localized growth inhibiter, on the stem elongation, branching, and flowering of Chrysanthemum morifolium Ramat. J. Amer. Soc. Hort. Sci. 101 : 599-604.

6. KLAPWIJK, D., J. W.H. van VEEN and P.J.A.L. de LINT. 1969. The effects of flower induction regimes and disbudding agents on sprayform of chrysanthemum. Acta Horticulturae $14: 221-227$.

7. KofraneK, A.M. and R. A. CRILEY. 1967. Emulsifiable oils as disbudding agents for chrysanthemum. Florists' Review $139: 24-$ $25,36,57-58$.

8. KOFRANEK, A. M. and L. MARKIEWICZ. 1967. Selected naphthalenes as disbudding agents for chrysanthemums. Florists Review 140 : $20-21,54-57$.

Q. KOFRANEK, A.M. 1970. Chemical disbudding of Chrysanthemum morifolium. HortScience $5: 46$.

10. Mastalerz, J. W. and F. L. CAMPBell. 1956. Maleic hydrazide- a substitute for pinching potted chrysanthemum. Proc. Amer. Soc. Hort. Sci. $68: 511-517$.

11. Nelson, P. V. and L.Z. Poteet. 1969. A preliminary investigation of chemical pruning of plants, some common questions and answers. Florists' Review $145: 19,50-53$.

12. PARUPS, E.V. 1977. Effectiveness of 2,3dihydro-5, 6-diphenyl-1, 4-oxathiin for disbudding of chrysanthemums grown under different environmental conditions. HortScience $12: 332-334$.

13. Pilllips, I. D. J. 1969. Apical dominance. In "The physiology of plant growth and development." M.B. Wilkins, ed., McGraw Hill, London, pp. 165-202.

14. Powell, E. N. and R. C. ANDREASEN. 1957. Responses of bench grown Chrysanthemum morifolium to maleic hydrazide. Proc. Amer. Soc. Hort. Sci. $70: 482-489$.

15. Sill, L. Z. and P. V. Nelson. 1970. Reaationship between azalea bud morphology and effectiveness of methyl decanoate, a chemical pinching agent. J. Amer. Soc. Hort. Sci. $95: 270-273$.

16. StefFens, G. L., T. C. Tso and D. W. SPAUldING. 1967. Fatty alcohol inhibition of tobacco axillary and terminal bud growth. J. Agr. Food Chem. $15: 972-975$.

17. Tso, T.C. 1964. Plant growth inhibition by some fatty acids and their analogues. Nature $202: 511-512$.

18. Tso, T.C., G. STeffens and M.E. ENGELHAUPT. 1965. Inhibition of tobacco axillary bud growth with fatty acid methyl esters. J. Agr. Food Chem. $13: 78-81$.

19. UHRING, J. 1971. Histological observations on chemical pruning of chrysanthemum with methyl decanoate. J. Amer. Scc. Hort. Sci. $96: 58-64$.

20. ZACHARIOUdAKIS, J. N. and R. A. LARSON. 1976. Chemical removal of lateral buds of Chrysanthemum morifolium Ramat. HortScience $11: 36-37$. 
キクの化学的摘らいに関する研究

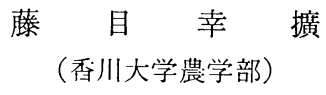

\begin{abstract}
侢
数種の化学物質を用い，主としてキクの化学的摘らい に関しその処理効果と処理方法を調べた.

1.トマトの “㳔病性：FR-1号”を用い，兮借的に 7 種類の化学物質につき摘芽効果を調べた結果, 次亜塩素 酸ソーダーとトミノー(壮香族有機化合物 $90 \%$ 一エチル トルエン,トリメチルベンゼン, $\mathrm{C}_{8} \sim \mathrm{C}_{12}$ の脂肪酸) が 最も有効であった. 葉の薬害発生は, 次亜塩素酸》ーダ 一処理で顕著であった
\end{abstract}

2. トマトに対するトミノーの摘芽作用は, 処理液の 付着部位についてのみ短時間に効果が現わ机た.

3. キクの “清水”を用い, 8 種類の化学物質につき

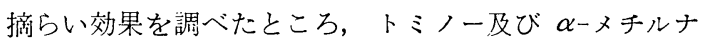

\section{要}

フタレンに摘らい効果が認められた.

4. ポットマム 4 品種を用い, 花らい形成時にトミ， 一 (2\%)を処理することにより, 全品種について先端の $4 \sim 5$ 節を残して, 他の側花らいに摘らい効果が認めら れた.

5. ポットマム 7 品種を用い, トミノー $(1,2 \%)$ の 処理時期及び前処理について調べた結果, 短日処理後 45 日目処理が最も効果的であった。 また，前処理として， 短日処理中に長日を 1 週間入れても，ほとんど摘らい効 果に影響は認められなかった。

6. トミノーを処理することにより, 茎の伸長はやや 抑兄られた。 